\title{
CORPORATE SOCIAL RESPONSIBILITY OF HEATING COMPANIES IN POLAND IN THE CONTEXT OF SUSTAINABLE DEVELOPMENT
}

doi:10.2478/czoto-2021-0035

Date of submission of the article to the Editor: $30 / 11 / 2020$

Date of acceptance of the article by the Editor: 19/03/2021

\author{
Aleksandra Wrzalik ${ }^{1}$ - orcid id: 0000-0002-3859-4954 \\ ${ }^{1}$ Czestochowa University of Technology, Poland
}

\begin{abstract}
In the coming years, the heating sector in Poland will undergo further changes as a result of the implementation of the country's energy policy within the European Union. Its main goals are: increasing energy efficiency, development of renewable energy sources and meeting legal and environmental requirements. Their implementation should take into account the observance of CSR principles in order to ensure a stable supply of heat to industrial and municipal consumers with high energy efficiency and limitation of the environmental impact. The article presents the conditions for the operation of the heating industry in Poland and CSR issues in heating companies. Particular attention was paid to the issue of energy poverty and its reduction. The application of social responsibility practices in heating industry on the basis of activities of selected enterprises in this sector was presented. The importance of social responsibility of heating companies in the implementation of a just energy transition in Poland was also indicated.
\end{abstract}

Keywords: corporate social responsibility, heating companies, energy poverty, sustainable development

\section{INTRODUCTION - CSR ISSUES IN ENTERPRISES}

Corporate Social Responsibility (CSR) expresses the company's responsibility for the impact of its functioning on society. The term CSR was formalized in 1953 by the American economist H.R. Bowen in his fundamental work Social Responsibility of the Businessman. It was the first comprehensive discussion on business ethics and social responsibility(Witkowska, 2016). The idea of CSR developed in the 1960s and 1970s along with the expansion of large corporations and became a popular subject in the 1980s with R.E. Freeman's Strategic Management: A Stakeholder Approach and the many key works of A.B. Carroll, P.F. Drucker, W.C. Frederick, H. Mintzberg and others (Carroll and Shabana, 2010). Over the years, the concept of CSR has significantly evolved and the emphasis is now on corporate and institutional practices based on high ethical standards, thanks to which companies voluntarily include environmental protection in their activities and create positive relations with various groups of stakeholders (Murphy and Schlegelmilch, 2013; Buczkowski et al., 2016). 
One of the broadest definitions of CSR was presented in 2010 by the International Organization for Standardization in the standard ISO 26000 Guidance on social responsibility, a document that integrates international expertise on the concept of the social responsibility of organizations in society (Hemphill, 2013; Buczkowski et al., 2016). According to it (ISO, 2010), CSR is "responsibility of an organization for the impacts of its decisions and activities on society and the environment, through transparent and ethical behaviour that:

- contributes to sustainable development, including health and the welfare of society;

- takes into account the expectations of stakeholder;

- is in compliance with applicable law and consistent with international norms of behaviour;

- is integrated throughout the organization and practised in its relationships."

The main principles and key thematic areas regulated by the ISO 26000 standard, as well as activities related to the implementation of CSR in the organization are presented in Figure 1.

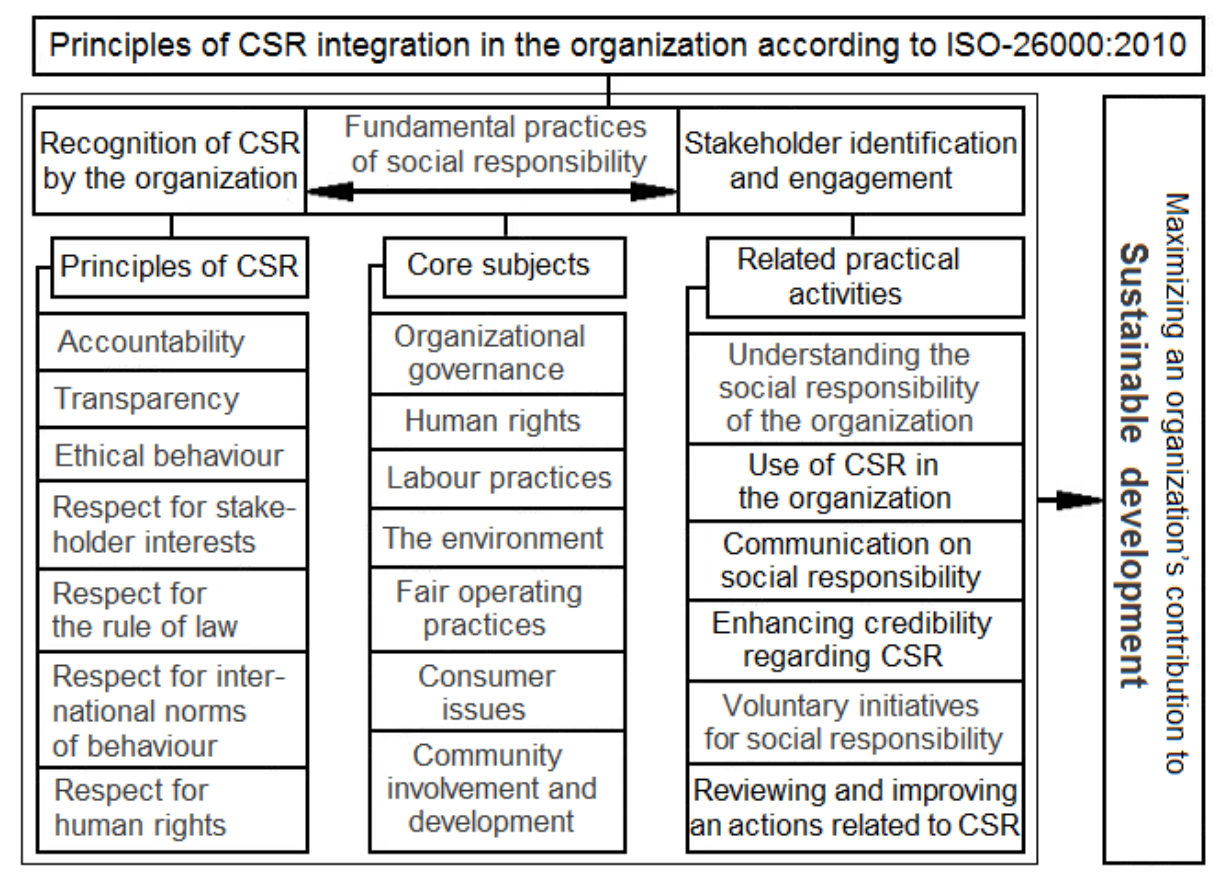

Fig. 1. Components of the social responsibility system of the organization Source: own elaboration based on the ISO 26000:2010 standard

The ISO 26000 standard serves to unify the understanding of CSR at the international level in various cultural, social, environmental and legal conditions. Apart from it, the main sources of international principles of corporate social responsibility are the UN Global Compact, the OECD Guidelines, the ILO Declaration and the European Commission's CSR strategy (Bernatt, 2009; ISO, 2019). Due to the dissemination of CSR, this issue is more and more often included in the company's management strategy.

\section{FACTORS AFFECTING THE HEATING SECTOR IN POLAND}

Although the energy sector determines the socio-economic development, it also affects the condition of the environment and climate changes on a global scale. That 
is why Poland, like other EU countries, implements a sustainable development strategy that includes efficient energy use, the development of renewable energy sources and cogeneration sources, reduction of greenhouse gas emissions and the implementation of energy-saving construction technologies (Ministerstwo Klimatu, 2020). The complexity of the factors influencing the development and directions of changes in the companies of the heating sector is shown in Figure 2.

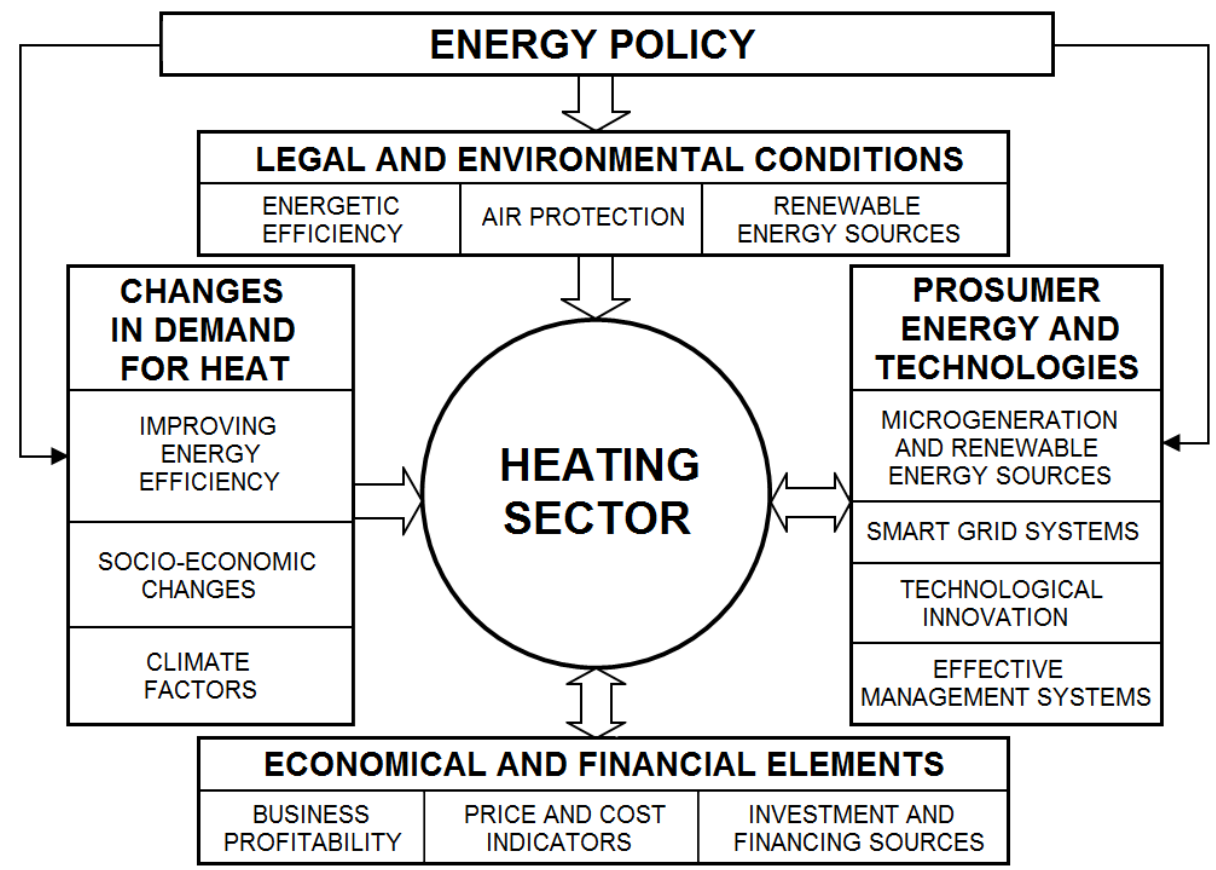

Fig. 2. Factors influencing the directions of changes in the heating sector Source: own elaboration

Poland's energy policy until 2040 sets the framework for a low-emission energy transformation in Poland and also covers heating (Ministerstwo Klimatu, 2020):

- 1st pillar - just transition (RES development and reducing energy poverty);

- 2nd pillar - zero-emission energy system (energy efficiency, distributed and prosumer energy);

- 3rd pillar - good air quality (development of energy-efficient heating systems and CHP sources, thermal modernization, zero-emission buildings).

Successful transformation, improvement of energy safety and efficiency as well as ecological indicators in the field of heat supply require comprehensive modernization and implementation of innovative technological solutions by heating companies. Innovations in heating must cover two areas: technical infrastructure (heat sources and district heating networks) and management of the heat generation and transmission system (Rak, 2018). This applies to all segments that make up the local heat markets (Turski and Sekret, 2015; Wojdyga and Chorzelski, 2017):

- heat production - just transition (RES development and reducing energy poverty);

- heat transfer - zero-emission energy system;

- building and installation systems at the recipients.

The future of heat supply systems is $4 G$ hybrid heating networks with reduced parameters, integrated within sustainable energy systems using renewable energy sources (Lund et al., 2014). 


\section{ENERGY POVERTY AND SUSTAINABLE DEVELOPMENT}

Today, almost 50 million people in the European Union are affected by energy poverty (EP). Due to the prevalence of this problem, reducing energy poverty has been identified as a key priority of the European Union's policy (Thomson et al., 2017;Górska, 2019). Energy poverty often defined as a situation where individuals or households are not able to adequately heat or provide other required energy services in their homes at affordable cost (Pay et al., 2015). The main cause of EP is the interaction between high energy prices, energy inefficient homes and appliances, and low household incomes (Oliveras et al., 2020).

One indicator that is used to compare energy poverty in Europe is the rate of inability to keep home adequately warm. According to Eurostat data (Fig. 3), the percentage of people suffering from energy poverty in EU Member States varies significantly and is less of a problem in colder countries than in warm ones.
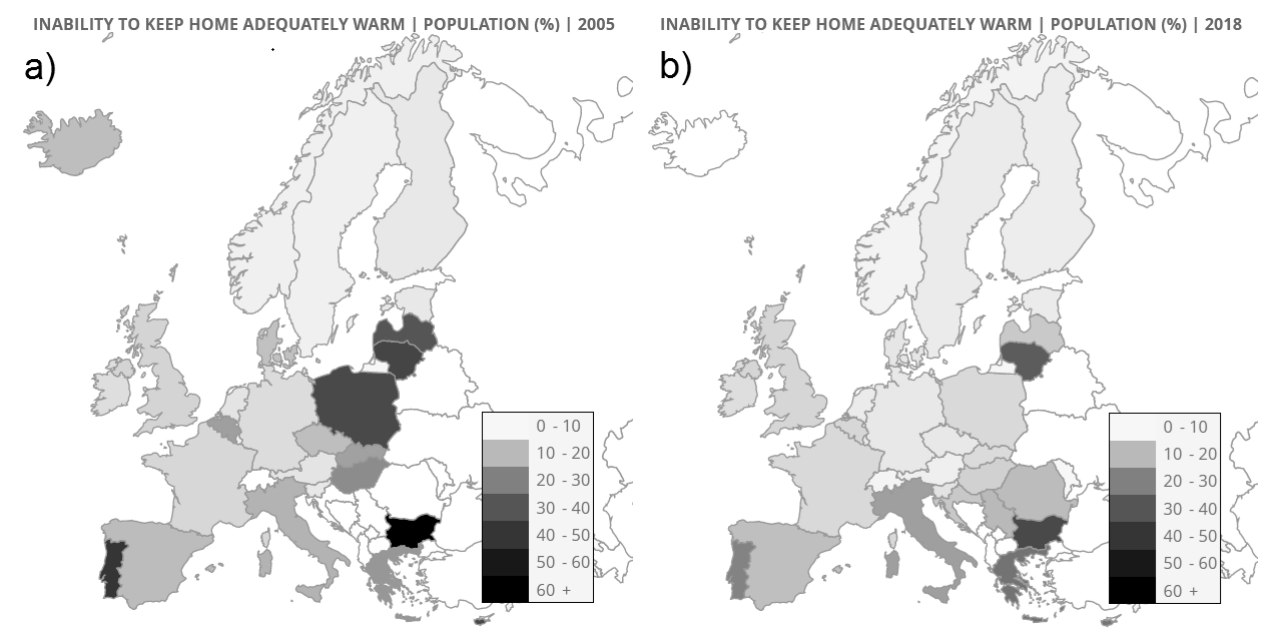

Fig. 3. Energy poverty indicators in UE countries in the years 2005 (a) and 2018 (b) Source: https://www.energypoverty.eu/indicators-data [access 20.11.2020]

The Scandinavian countries are leaders in terms of the efficiency of heating systems, the size of the share of households connected to these systems, as well as the use of modern, sustainable energy solutions (Upgrade DH, 2019). In Poland, the risk of energy poverty is moderate, but territorially diversified (Fig. 4).
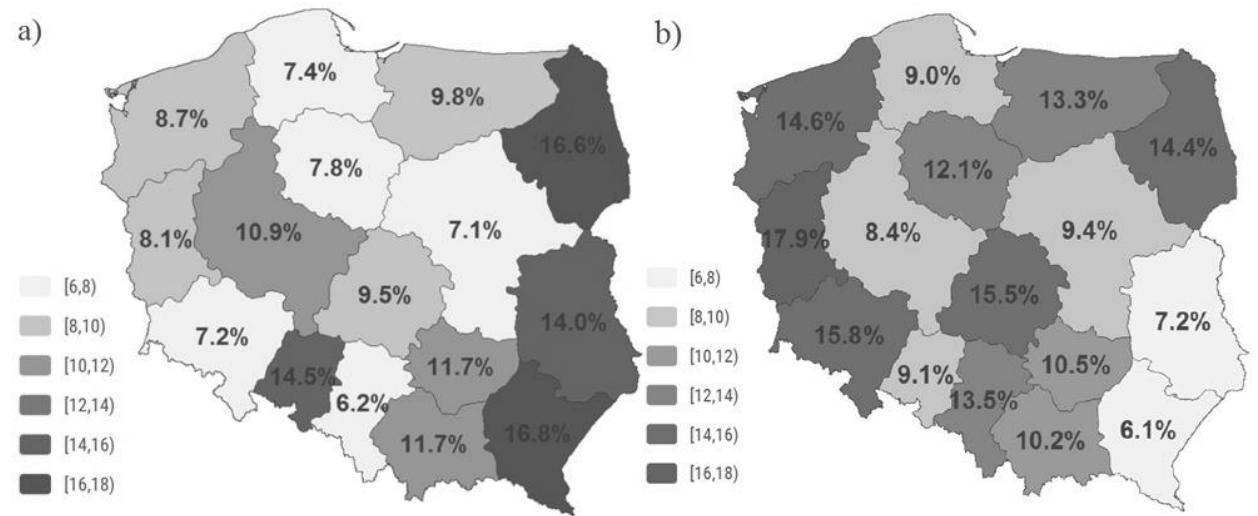

Fig. 4. The level of energy poverty in Poland in 2014 according to: a) LIHC index, b) subjective measure (failure to meet basic energy needs)

Source: Lis et al., 2016 
Households that spend too much on energy compared to their income (LIHC indicator) are more often rural residents at $62 \%$, while the largest percentage of socially sensitive recipients are retirees, farmers and manual workers (Fig. 5).

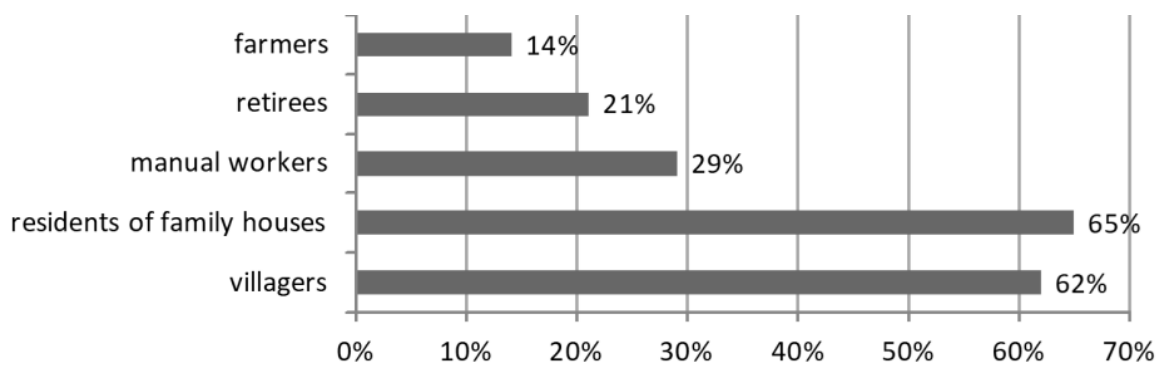

Fig. 5. Energy poverty in Poland in the groups of socially vulnerable consumers in 2014 according to the LIHC index

Source: Lis et al., 2016

We can distinguish three strategic areas of counteracting energy poverty: increasing household income, creating socially acceptable energy prices and improving the energy efficiency of buildings (Górska, 2019). These problems are included in the economic, social and environmental goals resulting from the sustainable development strategy implemented in the European Union. Poland, like the EU, has made reducing the scale of energy poverty one of its important priorities. It is assumed that by 2030 energy poverty will be reduced by $30 \%$, i.e. to a maximum level of $6 \%$ of households. The main tool to fight the problem of poverty is to improve the energy efficiency of buildings (thermal modernization) and to ensure effective and ecological access to heat (Ministerstwo Klimatu, 2020).The following will be important: state social assistance (energy allowance), pricing policy (Energy Regulatory Office), combining thermal modernization and renewable energy support programs with social assistance instruments and the involvement of heating companies as part of good CSR practices.

\section{IMPLEMENTATION OF CSR IN HEATING COMPANIES}

The implementation of corporate social responsibility practices is now part of the strategies of leading energy sector companies in Poland (Jaroń and Wędziński, 2010, PwC, 2012; Jacyno et al., 2013; Słupik, 2013). The hierarchy of goals of a heating company is shown in Figure 6.

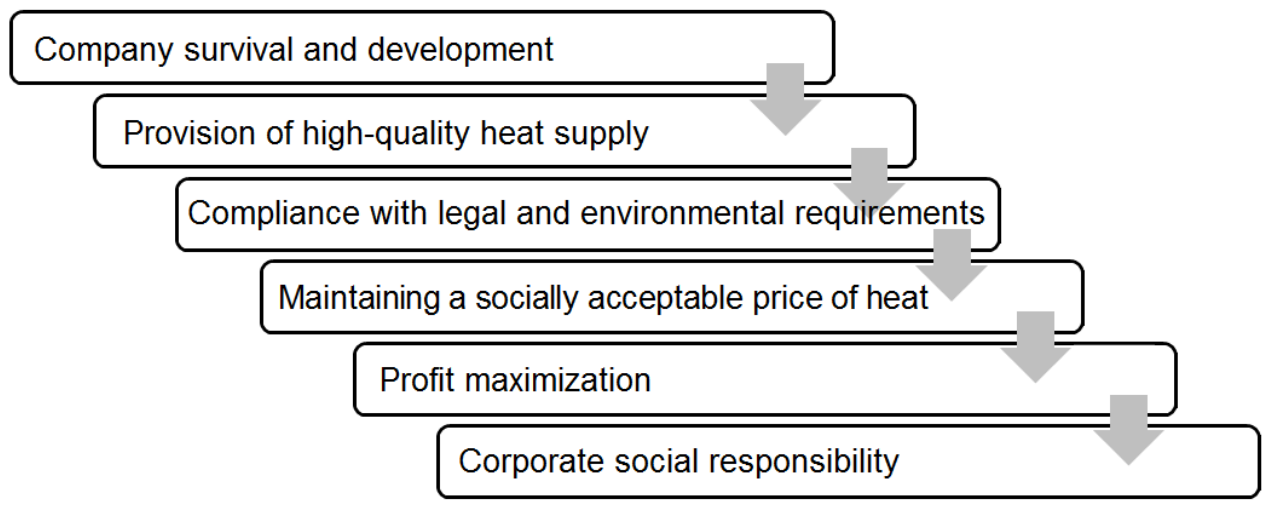

Fig. 6. Hierarchy of goals of a heating company

Source: based on Paszko, 2012 
It is worth emphasizing that in the case of enterprises from the thermal energy sector, the main goal, apart from survival and development, is to ensure the supply of heat, however, striving to maximize profit must be balanced with care for maintaining a socially acceptable cost of heat supply. Active relations and communication between the company and the social and economic environment are of great importance here. The involvement of an energy company in the life of the local community can effectively reduce the risk of social protests, e.g. in the case of the implementation of new investment projects, such as a waste incineration plant. Through information campaigns and promotion of energy-saving solutions and clean technologies for the sake of the environment, the local community can also be interested in energy security and more efficient use of energy (Jacyno et al., 2013).

Based on reports from 2012-2019 of seven representative energy sector enterprises, Table 1 shows the degree of involvement and activities of these companies in key areas of social responsibility.

Table 1.

Activities of selected energy enterprises in key areas of social responsibility (years 2012-2019)

\begin{tabular}{|l|c|c|c|c|c|c|c|}
\hline & \multicolumn{7}{|c|}{ Enterprises in the energy industry } \\
\cline { 2 - 9 } Key areas of activity & $\begin{array}{c}\text { Grupa } \\
\text { Veolia }\end{array}$ & $\begin{array}{c}\text { Grupa } \\
\text { GPEC }\end{array}$ & $\begin{array}{c}\text { Fortum } \\
\text { Power } \\
\text { and Heat }\end{array}$ & $\begin{array}{c}\text { Tauron } \\
\text { Polska } \\
\text { Energia }\end{array}$ & $\begin{array}{c}\text { EDF } \\
\text { Polska }\end{array}$ & PGNiG & PGE \\
\hline Corporate governance & 1 & 1 & 1 & 2 & 2 & 0 & 6 \\
\hline Labor relations & 5 & 12 & 0 & 12 & 14 & 9 & 13 \\
\hline Human rights & 1 & 1 & 0 & 1 & 3 & 0 & 0 \\
\hline Environment & 5 & 4 & 2 & 10 & 4 & 6 & 27 \\
\hline Fair operating practices & 0 & 0 & 0 & 2 & 1 & 1 & 3 \\
\hline $\begin{array}{l}\text { Social involvement and } \\
\text { development of society }\end{array}$ & 5 & 7 & 9 & 20 & 6 & 32 & 29 \\
\hline Consumer issues & 0 & 0 & 0 & 8 & 1 & 1 & 12 \\
\hline
\end{tabular}

Source: own elaboration based on http://odpowiedzialnybiznes.pl/dobre-praktyki/

The introduction of the principles of social responsibility by energy enterprises is associated with numerous economic and environmental benefits, as well as care for end users. In their activities, companies should be guided by openness, transparency and reliability, as well as resign from abusing their dominant position towards contractors, customers and energy recipients (Jaroń and Wędziński, 2010).

\section{CONCLUSION}

The concept of sustainable development implemented in EU countries through mechanisms promoting the increase in energy efficiency, the development of renewable energy sources, prosumer energy, digitization and implementation of innovative technologies is conducive to the energy transition. In this process, the activities of energy companies that directly affect the environment and society are of great importance. By adopting good CSR practices, heating companies, through sustainable development, combine the effectiveness of activities with the ecological and ethical aspects of their functioning in the social space. Including the corporate social responsibility practices of an energy company in a strategy that takes into account non- 
economic aspects of its operations may be a way to create a competitive advantage over other companies operating on the market.

It should be emphasized that in line with global CSR standards, environmental issues are of great importance in the energy sector, mainly in order to reduce greenhouse gas emissions and inform the public about the implementation of such activities (Jacyno et al., 2013). The effect of communication between the enterprise and the society is civic energy, i.e. the growing awareness of people and knowledge of how much they pay for energy, how energy affects their health, whether it degrades the environment, or creates an opportunity for them to actively participate in building energy security. CSR activities of energy companies also contribute to solving significant social problems, e.g. reducing energy poverty.

\section{REFERENCES}

Bernatt, M., 2009. Społeczna odpowiedzialność biznesu. Wymiar konstytucyjny i międzynarodowy, Wydawnictwo Naukowe Wydziału Zarządzania Uniwersytetu Warszawskiego, Warszawa.

Buczkowski, B., Dorożyński, T., Kuna-Marszałek, A., Serwach, T., Wieloch, J., 2016. Społeczna odpowiedzialność biznesu. Studia przypadków firm międzynarodowych, Wydawnictwo Uniwersytetu Łódzkiego, Łódź.

Carroll, A.B., Shabana, K.M., 2010. The Business Case for Corporate Social Responsibility: A Review of Concepts, Research and Practice, International Journal of Management Reviews, 85-105. DOI:10.1111/j.1468-2370.2009.00275x

Górska, A., 2019. Unia Europejska wobec problemu ubóstwa energetycznego w wybranych państwach członkowskich, Fundacja na Rzecz Czystej Energii, Poznań.

Hemphill, T., 2013. The ISO 26000 guidance on social responsibility international standard: what are the business governance implications?, Corporate Governance, 13 (3), 305-317, DOI:10.1108/CG-08-2011-0062

https://www.energypoverty.eu/indicators-data [access 20.11.2020]

http://odpowiedzialnybiznes.pl/dobre-praktyki/ [access 24.11.2020]

ISO, 2010. International Standard ISO 26000. Guidance on social responsibility.ISO copyright office, Geneva. https://iso26000.info/wp-content/uploads/2017/06/ISO26000_2010_E_OBPpages.pdf [access 20.11.2020]

ISO, 2019. ISO 26000 and OECD Guidelines. Practical overview of the linkages. https://www.iso.org/publication/PUB100418.html [access 20.11.2020]

Jacyno, M., Korkosz-Gębska, J., Maj, M., Milewski, J., Trębacz, D., Wójcik, G., 2013. Społecznie odpowiedzialna energetyka, Rynek Energii, 6 (109), 3-12.

Jaroń ,P., Wędziński ,Ł., 2010. Korzyści dla przedsiębiorstw sektora energetycznego wynikające z implementacji zasad Społecznej Odpowiedzialności Biznesu, Biuletyn Urzędu Regulacji Energetyki, 2 (70), 2-7.

Lis, M., Miazga, A., Sałach, K., Szpor, A., Święcicka, K., 2016. Ubóstwo energetyczne w Polsce - diagnoza i rekomendacje, Instytut Badań Strukturalnych.

Lund, H., Werner, S., Wiltshire, R., Svendsen, S., Thorsen, J.E., Hvelplund, F., Mathiesen, B.V., 2014. 4th Generation District Heating (4GDH): Integrating smart thermal grids into future sustainable energy systems. Energy, 68, 1-11, DOI: 10.1016/j.energy.2014.02.089

Ministerstwo Klimatu, 2020. Polityka energetyczna Polski do 2040 r. (PEP2040).https://www.gov.pl/web/klimat/polityka-energetyczna-polski [access 26.11.2020] 
Murphy, P.E., Schlegelmilch, B.B., 2013. Corporate social responsibility and corporate social irresponsibility: Introduction to a special topic section, Journal of Business Research, 66(10), 1807-1813, DOI: 10.1016/j.jbusres.2013.02.001

Oliveras, L., Peralta, A., Palència, L., Gotsens M., López, M.J., Artazcoz, L., Borrell, C., Marí-Dell'Olmo, M., 2020. Energy poverty and health: Trends in the European Union before and during the economic crisis, 2007-2016, Health \& Place. DOI: 10.1016/j.healthplace.2020.102294

Paszko, P., 2012. Strategiczne opcje rozwoju przedsiębiorstwa energetyki cieplnej. http://dise.org.pl/publikacje/bezpieczenstwo_energetyczne/strategiczne_opcje_rozwoju_przedsiebiorstwa.pdf [access 15.11.2020]

Pye, S., Dobbins, A., Baffert, C., Brajković, J., Grgurev, I., Miglio, D.R., Deane, P., 2015.Energy Poverty and Vulnerable Consumers in the Energy Sector Across the EU: Analysis of Policies and Measures, London, Insight_E.

PwC, 2012. Odpowiedzialna energia. Wyzwania zrównoważonego rozwoju branżyenergetycznej.

https://www.pwc.pl/pl/publikacje/pwc_odpowiedzialna_energia.pdf[access 30.11.2020].

Rak, A., 2018. Selected aspects of technological innovations management in district heating companies. MATEC Web of Conferences, 183.

DOI: 10.1051/matecconf/201818304003

Słupik, S., 2013. Strategia społecznej odpowiedzialności biznesu w działalności przedsiębiorstw energetycznych w Polsce. Studia Ekonomiczne Uniwersytet Ekonomiczny w Katowicach, 136, 257-265.

Thomson, H., Bouzarovski, S., Snell, C., 2017. Rethinking the measurement of energy poverty in Europe: A critical analysis of indicators and data. Indoor and Built Environment, 26(7), 879-901, DOI: 10.1177/1420326X17699260

Turski, M., Sekret, R., 2015. Konieczność reorganizacji systemów ciepłowniczych $w$ świetle zmian zachodzących $w$ sektorze budowlano-instalacyjnym. Rynek Energii, 4, 27-34.

Upgrade DH, 2019. Upgrading the performance of district heating networks. Technical and non-technical approaches. A Handbook. WIP Renewable Energies, Munich, Germany.

Witkowska, J., 2016. Społeczna odpowiedzialność biznesu, [w:] Wysokińska, Z., Witkowska, J., Zrównoważony rozwój. Wybrane aspekty makro- i mikroekonomiczne. Wydawnictwo Uniwersytetu Łódzkiego, Łódź.

Wojdyga, K., Chorzelski, M., 2017. Chances for polish district heating systems. Energy Procedia, 116, 106-118, DOI: 10.1016/j.egypro.2017.05.059. 